\title{
Potential of Bioactive Components in Tempe for the Treatment of Obesity
}

\author{
Made Astawan $^{1 *}$, Yunita Siti Mardhiyyah ${ }^{1}$, Christofora Hanny Wijaya ${ }^{1}$ \\ ${ }^{1}$ Department of Food Science and Technology, Faculty of Agricultural Engineering and Technology, \\ Bogor Agricultural University, Bogor 16680
}

\begin{abstract}
Obesity has become a global health issue and is one of the factors that trigger degenerative diseases. The correct food consumption management could be a solution for treating obesity. Soybean is a food that is rich in bioactive components and has antiobesity properties through various mechanisms. In Indonesia, nearly $60 \%$ of the soybeans are consumed in the form of tempe. The process of fermenting soybeans into tempe causes a bioconversion of nutrients and bioactive components, improving the active physiological abilities. The bioactive components that play a role in the treatment of obesity are isoflavones, proteins, and peptides. These bioactive components help in reducing body weight, lowering the body fat ratio and improve lipid profile. Thus, optimation and popularization of tempe as a functional food in the daily menu supported with correct tempe processing could be a solution in treating obesity.
\end{abstract}

Keywords: isoflavones, obesity, protein, soybean, tempe

\section{INTRODUCTION}

Obesity has become a worldwide health issue and is believed to be one of the factors that trigger degenerative diseases and metabolic problems such as diabetes mellitus (DM), coronary heart diseases (CHD), dyslipidemia, hypertension, and arthritis (Yuliana et al. 2011; Velasquez \& Bhathena 2007). WHO (2014) highlighted that $65 \%$ of the world population is overweight and obese and has a higher mortality risk than malnourished people. Based on the WHO standard, a BMI greater than $25 \mathrm{~kg} / \mathrm{m}^{2}$ is categorized as overweight, and a BMI greater than $30 \mathrm{~kg} / \mathrm{m}^{2}$ is categorized as obese.

Aside from the lack of physical activities, poor food consumption pattern such as excessive consumption of foods rich in fat and carbohydrate is considered as a main cause of obesity (WHO 2011). Therefore, strategies in treating obesity include reduction of the amount of energy absorbed by the body, using appetite suppressants, inhibiting nutrient absorption, increasing metabolism, and lipid modulation (inhibiting the differentiation and proliferation of adipocytes, and reducing lipogenesis and increasing lipolysis) (Yun 2010).

Complications due to obesity and other degenerative diseases have encouraged the consumption of low-energy, low-fat, high-fiber, and antioxidant-rich foods (Bhathena \& Velasquez 2002). Soybeans have been reported to contain such quality, it has various bioactive components which have active physiological properties in treating obesity (Bhathena \& Velasquez 2002; Velasquez \& Bhathena 2007). In Indonesia, nearly $60 \%$ of soybeans are consumed in the form of tempe with an average tempe consumption of $10.1 \mathrm{~kg}$ per person per year (Astawan et al. 2017). The process of fermenting soybeans into tempe can also improve its nutritional value and benefits for health (Nout \& Kries 2005; Astawan 2008).

Many studies pertaining to the use of soybeans and soybean products in the treatment of obesity have been conducted, however not many discuss the possibilities of utilizing tempe which is a fermented soybean product as a component in treating obesity. Against this backdrop, the review will discuss the possibilities of using tempe as a soybean-derived functional food in the treatment of obesity.

\section{The Bioactive components of soybeans and tempe}

The main ingredient of tempe is soybeans (Glycine max), therefore bioactive components of soybeans (Table 1) would most likely be found in tempe, or might even be more "activated" due to the fermentation process. Tempe is made from soybean through a number of steps, namely soaking, boiling, removing the cotyledon husk, adding mold (the mold Rhizopus spp.), and fermenting at $30-37^{\circ} \mathrm{C}$ for $36-48$ hours (Nout \& Kries 2005). Fermentation changes various compo-

"Corresponding Author: tel: +62251-8626725; email: mastawan@yahoo.com 
nents in soybeans, producing tempe which has an enhanced nutritional content and improved bioactive components and is more beneficial for health than soybeans (Astawan et al. 2017). Table 1 shows the bioactive components in soybean and the benefit for health.

The technology of tempe-making is "adopted" in food technology as the term Solid State Bioconversion (SSB) or Solid State Fermentation (SSF) by exploiting various molds which are usually used in traditional fermentation processes such as Rhizopus sp, Aspergillus sp., Bacillus sp., et cetera (Maiti \& Majumdar 2012; McCue et al . 2005; Sanchez-Magana et al. 2014). Fermentation of soybeans using the mold Rhizopus spp. is favored because the application is simple and able to produce products with a palatable flavor (Sanchez-Magana et al. 2014; Wijaya et al. 2007).

Fermentation will increase the content of small molecules such as free fatty acids and amino acids (Ali et al. 2016) and the isoflavone aglycone (Haron et al. 2009), as well as produce bioactive peptides (Gibbs et al. 2004). This is due to the enzymatic activity of microorganisms which works on the soybean substrate, for example, lactic acid bacteria (BAL), mold, and yeast (Gibbs et al. 2004; Barus et al. 2008). Singh et al. (2014) reported that fermentation with BAL is also commonly used for the production of bioactive peptides. These bioactive components will lend active physiological properties for health.

The amount and types of bioactive components produced during the fermentation of tempe are influenced by the enzymatic activities of the microorganisms. Efriwati and Nuraida (2013) demonstrated that differences during the tempe production process will yield different macronutrient components (carbohydrate, fat, and protein) in the tempe and also differences in the isoflavone content. Differences in the tempe production method create a possibility for different microbes to exist and to take part in the tempe fermentation process (Barus et al. 2008). The differences in microorganisms will determine the differences in proteolytic, lipolytic, and glycolytic activities, and these will determine differences in the bioconversion of fat, protein, carbohydrate and other components (Tope 2014).

A number of in vitro tests revealed a few bioactive components in soybeans and products derived from soybeans that play a role in the treatment of obesity such as phenolic (isoflavone) component and peptides. Some of the mechanisms of these components can be seen in Table 2.

Table 1. The bioactive components in soybeans and the benefits for health (Sugano 2006)

\begin{tabular}{ll}
\hline \multicolumn{1}{c}{ Component } & \\
\hline Protein & Hypocholesterolemic, antiatherogenic, reduces weight \\
Peptide & Easily absorbed, reduces weight \\
Lectin & Immunity, anticarcinogenic \\
Trypsin inhibitor & Anticarcinogenic \\
Dietary fiber & $\begin{array}{l}\text { Improves the function of the digestive tract, prevents colon cancer, regulates the metabolism } \\
\text { of fat }\end{array}$ \\
Oligosaccharide & Prebiotic, improves the function of the digestive tract \\
Phytin & Regulates carbohydrate metabolism, anticarcinogenic, aids in mineral absorption \\
Saponin & Regulates fat metabolism, antioxidant \\
Isoflavone & Esterogen functions, prevents osteoporosis, anticarcinogenic \\
Linoleic acid & Essential fatty acid, hypocholesterolemic \\
Linolenic acid & Essential fatty acid, hypocholesterolemic, improves the function of the cardiovascular sys- \\
& tem, antiallergy \\
Lecithin & Increases the metabolism of fat, maintains nervous functions \\
Tocopherol & Antioxidant, prevents cardiovascular diseases \\
Sterol & Hypocholesterolemic, prevents prostate cancer \\
Vitamin K & Aids in blood clotting, prevents osteoporosis \\
Mg & Essential mineral, prevents cardiovascular problems \\
\hline
\end{tabular}


Table 2. Bioactive components in tempe for the treatment of obesity

\begin{tabular}{|c|c|c|c|c|}
\hline Product & $\begin{array}{l}\text { Bioactive } \\
\text { component }\end{array}$ & Research method & $\begin{array}{c}\text { Active physiological } \\
\text { properties }\end{array}$ & References \\
\hline $\begin{array}{l}\text { Soybean tempe } \\
\text { with R.oligosporus } \\
\text { NRRL } 2710\end{array}$ & $\begin{array}{l}\text { E peptide and I } \\
\text { peptide }\end{array}$ & $\begin{array}{l}\text { Antioxidant through } \\
\text { the ferric thiocyanate } \\
\text { method }\end{array}$ & $\begin{array}{l}\text { Positive antioxidant activity, } \\
\text { and E peptide also has an ACE } \\
\text { inhibition property with an } \\
\mathrm{IC}_{50} \text { of } 0.6 \pm 0.1 \mu \mathrm{M}\end{array}$ & $\begin{array}{l}\text { Gibbs et al. } \\
(2004)\end{array}$ \\
\hline $\begin{array}{l}\text { Solid state biopro- } \\
\text { cessed soybeans } \\
\text { with R.oligosporus }\end{array}$ & $\begin{array}{l}\text { Phenolic com- } \\
\text { ponent }\end{array}$ & $\begin{array}{l}\text { Inhibition of amylase, } \\
\alpha \text {-glucosidase, and } \\
\text { antioxidant through } \\
\text { the DPPH method }\end{array}$ & $\begin{array}{l}\text { Maximum inhibition of amy- } \\
\text { lase on day } 4 \text { of fermentation } \\
\text { with an inhibition index (AI) } \\
\text { of } 2.08 \text {. Highest glucosidase } \\
\text { inhibition on day } 6 \text { of fermen- } \\
\text { tation, } \mathrm{AI}=1.1 \text {. A correlation of } \\
\mathrm{R}=0.85 \text { between antioxidant } \\
\text { activity and amylase inhibition }\end{array}$ & $\begin{array}{l}\text { McCue et al. } \\
(2005)\end{array}$ \\
\hline $\begin{array}{l}\text { Solid state bio- } \\
\text { conversion (SSB) } \\
\text { of soybeans with } \\
\text { R.oligosporus }\end{array}$ & $\begin{array}{l}\text { Phenolic com- } \\
\text { ponent }\end{array}$ & $\begin{array}{l}\text { Inhibition of amylase, } \\
\alpha \text {-glucosidase, and } \\
\text { antioxidant through } \\
\text { the DPPH method }\end{array}$ & $\begin{array}{l}\text { Highest antioxidant on fermen- } \\
\text { tation day } 4,57.4 \% \text { higher than } \\
\text { soybeans without fermenta- } \\
\text { tion, highest amylase inhibi- } \\
\text { tion on day } 6 \text { of fermentation, } \\
\mathrm{AI}=3.6 \text {, highest glucosidase } \\
\text { inhibition on day } 6 \text { of fermen- } \\
\text { tation, } \mathrm{AI}=2.0\end{array}$ & $\begin{array}{l}\text { Maiti and Ma- } \\
\text { jumdar (2012) }\end{array}$ \\
\hline
\end{tabular}

\subsection{Phenolic component and isoflavone}

In Indonesia, soybeans are processed into tempe, tofu, soy sauce, tauco, and soymilk. Among those soybean products, tempe is the food with the highest isoflavone aglycone thus provide higher bioavailability compared to other soybean products (Haron et al. 2009). Raw tempe has an isoflavone content of $54 \mathrm{mg} / 100 \mathrm{~g}(\mathrm{bb})$, while tofu and soymilk have a lower isoflavone content of 43 and $28 \mathrm{mg} / 100 \mathrm{~g}$ (bb), respectively.

Mold fermentation helps activate the soybean's isoflavone component (Figure 1) from the glycone form (daidzin and genistin) to aglycone (daidzein and genistein) that are more readily absorbed by the body (Astawan 2008) and also increases the antioxidant activity (Astawan et al. 2013). Efriwati and Nuraida (2013) found that the genistein and daidzein contents of tempe were 9.4-10.0 and 93.4-101.2 mg/100 g tempe (b.k), respectively. Haron et al. (2009) found that the total isoflavone aglycone was $54 \mathrm{mg} / 100 \mathrm{~g}$ tempe (b.k) with almost identical amounts of daidzein and genistein, $26 \pm 6 \mathrm{mg}$ and $28 \pm 11 \mathrm{mg}$.

The bioconversion of glycone isoflavone and the improved bioavailability of isoflavone would increase the active physiological properties of tempe in comparison to soybean, for example in condition such as hypotriacylglycerol (Watanabe et al. 2006) and hypocholesterolemic (Astuti 1997) that usually occur in obesity cases.
Figure 1 shows the chemical structure of soybean isoflavones according to Shao et al. (2009).

Isoflavones also play many roles in the inhibition of carbohydrate-digesting enzymes. Lee and Lee (2001) demonstrated that genistein is an effective $\alpha$-glucosidase enzyme inhibitor, is reversible, slow-binding and non-competitive. The product of soybean fermentation using $R$. oligosporus demonstrated an amylase inhibition of 1.5-2.0 AI (Amylase Inhibition Index) which correlated with the total phenol value $(\mathrm{R}=0.59)$ (McCue et al. 2005; Maiti \& Majumdar 2012).

In addition, Genistein also has a potential as an antiobesity through the activation of the AMP-activated kinase (AMPK) in the inhibition of lipid differentiation (Hwang et al. 2005). Genistein (20-200 uM) could significantly inhibit $90 \%$ of adipose tissue differentiation from 3T3L1 cells and also induce apoptosis $(43 \%)$ in mature adipose tissue (Hwang et al. 2005). In vivo testing of $0.2 \%$ genistein $+0.5 \%$ L-carnitine in C57BL/6J rats with high-fat feed demonstrated a decrease in body weight of $254 \%$ after 12 weeks of the experiment. This was believed to be due to a PPAR activation inhibition mechanism (Yang et al. 2006). Numerous benefits of soybean isoflavones and their increased amount in tempe create an opportunity to utilize tempe in the treatment of obesity. 


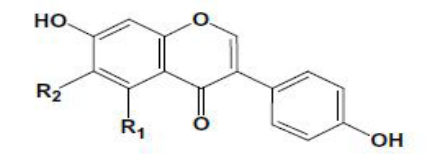

Aglycones

Daidzein $\mathrm{R}_{1}=\mathrm{H} \quad \mathrm{R}_{2}=\mathrm{H}$ Glycitein $\mathrm{R}_{1}=\mathrm{H} \mathrm{R}_{2}=\mathrm{OCH}_{3}$ Genistein $\mathrm{R}_{1}=\mathrm{OH} \mathrm{\textrm {R } _ { 2 }}=\mathrm{H}$

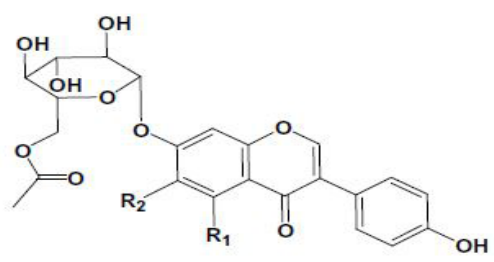

6"-O-Acetyl-7-O- $\beta$-D-Glucosides

Acetyl Daidzin $\mathrm{R}_{1}=\mathrm{H} \quad \mathrm{R}_{2}=\mathrm{H}$

Acetyl Glycitin $\mathrm{R}_{1}=\mathrm{H}_{2} \mathrm{R}_{2}=\mathrm{OCH}_{3}$

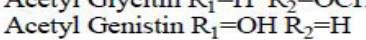

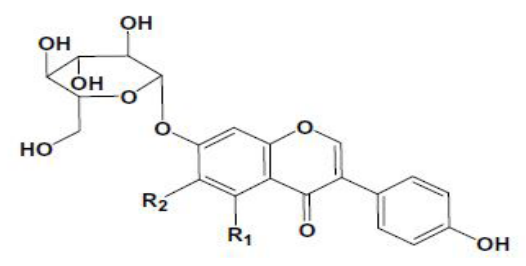

7-O- $\beta$-D-Glucosides

Daidzin $\mathrm{R}_{1}=\mathrm{H}_{2}=\mathrm{H}$

Glycitin $\mathrm{R}_{1}=\mathrm{H} \mathrm{R}_{2}=\mathrm{OCH}_{3}$

Genistin $\mathrm{R}_{1}=\mathrm{OH} \mathrm{R_{2 }}=\mathrm{H}$

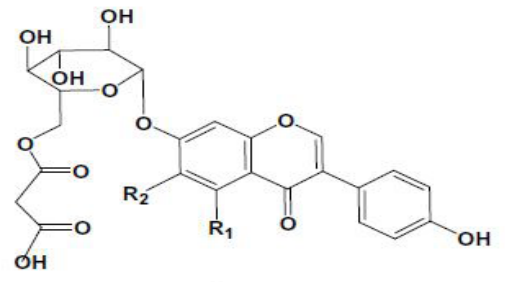

6"-O-Malonyl-7- $\beta-D-G l u c o s i d e s$

Malonyl Daidzin $\mathrm{R}_{1}=\mathrm{H} \quad \mathrm{R}_{2}=\mathrm{H}$

Malonyl Glycitin $\mathrm{R}_{1}=\mathrm{H} \mathrm{R}_{2}=\mathrm{OCH}_{3}$

Malonyl Genistin $\mathrm{R}_{1}=\mathrm{OH} \mathrm{R} \mathrm{R}_{2}=\mathrm{H}$

Figure 1. The chemical structure of soybean isoflavones (Shao et al. 2009)

\subsection{Protein and or peptides}

Other components of soybeans that play a part in obesity treatment are protein and peptides. Wang and Huang (1984) discovered a protein found in soybean, sunflower seeds, peanuts, and cucumber seeds which have an antiobesity potential through a lipase inhibition mechanism. The inhibition effect was strongly influenced by heat and the role of protease and was not dependent on the amount of the enzyme lipase but depended on the amount of substrate. A large amount of substrate eliminated the lipase inhibition effect, thus in the application, limitation of fat consumption was also required for an optimum lipase inhibition benefit.

The lipase inhibition mechanism is believed to be through the binding of protein on the surface of the substrate micelle, preventing the normal lipase function which works on the interfacial area between the medium (water) and the surface of the micelle (Wang \& Huang 1984). This soybean protein component is believed to still be present in tempe, or the lipase inhibition activity in tempe could still be maintained by other, smaller proteins or peptides produced through tempe fermentation. Gibbs et al. (2004) demonstrated an increase in dissolved protein in tempe compared to soybean, plus antioxidant properties and other active physiological actvities.

Singh et al. (2014) stated that bioactive peptides from soybeans and its products also have antiobesity properties through a number of mechanisms such as anorexia or appetite suppression, inhibition of lipogenesis in the liver (decreasing the triglyceride and cholesterol levels in the blood), and inhibition of the activation of the hormone cholecystokinin (CCK), causing satiety. Jang et al. (2008) stated that in overweight rats induced by high-fat feed, supplementation of peptides from black soybeans for 13 weeks has shown weight loss, decreased leptin level and decreased appetite compared to the controls.

\section{The Effect of soybeans and tempe in obesity treatment}

A few in vivo studies related to the effect of soybean and or tempe consumption on obese test animals can be seen in Table 3. Obesity is usually associated with insulin resistance and abnormalities in lipid metabolism in the form of increased overall lipid production such as increased free fatty acids, triglycerides, and LDL (Yuliana et al. 2011). Metabolomic issues such as dyslipidemia and or diabetes as an effect of obesity can be managed by consuming soybeans, soybean products such as tempe, or soybean hydrolysate as a source of protein. Watanabe et al. (2006) and Astawan et al. (2015) demonstrated an improvement in lipid profile, especially an increase in HDL due to consumption of tempe feed (isocaloric) compared to consumption of casein or soybean. 
Table 3. In vivo studies related to the effect of soybean and or tempe consumption on obesity treatment

\begin{tabular}{|c|c|c|c|c|}
\hline Model & Feed and Amount & Time & Results & References \\
\hline Wistar male rats & $\begin{array}{l}\text { Three groups: casein, soy- } \\
\text { bean, and tempe-GABA } \\
\text { with } R \text {. microspores inocu- } \\
\text { lum fermented aerobically } \\
\text { and anaerobically. } \\
\text { Isoprotein }(30 \%) \text {, previ- } \\
\text { ously fed high-fat feed } \\
(20 \%)\end{array}$ & 6 weeks & $\begin{array}{l}\text { No difference in weight. } \\
\text { A significant difference in cholesterol } \\
\text { and triacylglyceride levels in plasma, } \\
\text { namely casein>soybean>tempe-GA- } \\
\text { BA. } \\
\text { The highest HDL in the tempe-GABA } \\
\text { group. } \\
\text { The highest LDL in the casein group. }\end{array}$ & $\begin{array}{l}\text { Watanabe } \\
\text { et al. }(2006)\end{array}$ \\
\hline $\begin{array}{l}\text { Adult male } \\
\text { Sprague-Dawley } \\
\text { rats and yellow } \\
\text { KK mice, made } \\
\text { obese }\end{array}$ & $\begin{array}{l}\text { Three groups: casein, pro- } \\
\text { tein soybean isolate (SPI), } \\
\text { and soybean protein hy- } \\
\text { drolysate (SPI-H) } \\
\text { Low-calorie feed }(60 \%) \text {, } \\
\text { high protein }(35 \%) \text { and } \\
\text { low fat }(5 \%) \text {, previously } \\
\text { fed high-fat feed }(30 \%)\end{array}$ & 4 weeks & $\begin{array}{l}\text { Adult rats: lower fat absorption in SPI } \\
\text { and SPI-H compared to that in casein, } \\
\text { total cholesterol, and blood glucose } \\
\text { lower in SPI-H. } \\
\text { Mice: significantly lower body fat in } \\
\text { SPI and SPI-H than in casein. }\end{array}$ & $\begin{array}{l}\text { A o y a m a } \\
\text { et al. } 2000 \mathrm{a}\end{array}$ \\
\hline $\begin{array}{l}\text { Male yellow } \\
\text { KK mice, made } \\
\text { obese }\end{array}$ & $\begin{array}{l}\text { Four groups: casein } \\
\text { (WPI), casein hydrolysate } \\
\text { (WPI-H), soybean protein } \\
\text { isolate (SPI), and soybean } \\
\text { protein hydrolysate isolate } \\
\text { (SPI-H) } \\
\text { Feed as in Aoyama et al. } \\
\text { 2000a }\end{array}$ & 2 weeks & $\begin{array}{l}\text { A significant descrease in the body } \\
\text { weight of SPI-H rats compared to WPI } \\
\text { and WPI-H. Total plasma cholesterol, } \\
\text { blood glucose, and body fat level lower } \\
\text { in SPI-H than in WPI and WPI-H. }\end{array}$ & $\begin{array}{l}\text { A o y a m a } \\
\text { et al. } 2000 \mathrm{~b}\end{array}$ \\
\hline $\begin{array}{l}\text { Obese (weight: } \\
125 \mathrm{~g}) \text { and nor- } \\
\text { mal }(96 \mathrm{~g}) \text { SHR/ } \\
\text { N-cp rats }\end{array}$ & $\begin{array}{l}\text { Fours groups: } 20 \% \text { casein } \\
\text { (normal), casein }+0.1 \% \\
\text { isoflavone, casein }+0.1 \% \\
\text { probiotic, casein }+0.1 \% \\
\text { isoflavone }+0.1 \% \text { probi- } \\
\text { otic; Isocaloric. }\end{array}$ & $\begin{array}{c}20 \\
\text { weeks }\end{array}$ & $\begin{array}{l}\text { The isoflavone group had a significant } \\
\text { loss of body weight, epididymal, peri- } \\
\text { renal, subdiaphragmatic, ileal fat pad } \\
\text { fat weight, and total cholesterol com- } \\
\text { pared to the other treatments in obese } \\
\text { rats. }\end{array}$ & $\underset{2004}{\text { Ali }}$ et al. \\
\hline
\end{tabular}

An experiment using low calorie (60\%), high protein (35\%) and low fat (5\%) feed in obese rats demonstrated a decrease in body weight and an improvement in the condition of the body fat in rats fed with soybean protein isolate and soybean hydrolysate compared to those fed with casein and milk protein hydrolysate (Aoyama et al. 2000a, Aoyama et al. 2000b). The mechanism involved were decrease in perirenal fat and blood glucose concentration. Furthermore, Kagawa et al. (1996) suspected that the fat reduction effect was due to the activity of the tetrapeptide found in soybeans.

In addition to protein and or peptides activities, the decrease in body weight and the improvement in the lipid condition was also due to the activity of isoflavone (genistein, daidzein, and glycitein) (Ali et al. 2004) found in soybeans and tempe. Further, Watanabe et al. (2006) demonstrated that the protein, isoflavone and free amino acid components in tempe had a better hypotriacylglyceride effect than soybeans or casein.

Tempe, which contain protein composition that has been fermented into peptides (similar to the condition in soybean protein hydrolysate) and supported by higher isoflavone component than soybeans (Haron et al. 2009) or soybean hydrolysate, is of course expected to have more benefits for health including for obesity treatment. Unfortunately, no studies in place aimed at pertaining to this subject. The author has not found any clinical studies regarding the use of tempe in humans for the purpose of obesity control. However, one human study conducted by Astuti (1997) has demonstrated the benefits of tempe in improving the lipid or dyslipidemia status which is also commonly found in obesity cases (Table 4).

Many clinical studies pertaining to the use of soybeans in obesity treatment have been 
Table 4. Studies in humans pertaining to the effect of consuming soybeans and or tempe in obesity treatment (Astuti 1997)

\begin{tabular}{cll}
\hline Product & Research method & Results \\
\hline Tempe formula-based food & 24 volunteers (8 men, 16 wom- & A decline in total cholesterol (8.6\% in men, \\
& en), daily consumption of a tem- & $10.25 \%$ in women), a decline in LDL (12\% \\
pe-based drink for three months & $\begin{array}{l}\text { in men, 9.67\% in women), a decline in MDA } \\
(23 \% \text { in men, 15\% in women). }\end{array}$ \\
\hline
\end{tabular}

conducted. Cope et al. (2008) reported in a review that a number of soybean-based food products will reduce body weight and eliminate fat when consumed isocalorically. This was proven through in vivo testing using model animals, though there are very few supporting clinical studies in humans.

Zhang et al. (2013) have conducted a meta-analysis of the efficacy of the consumption of a soybean isoflavone supplement on body weight, fasting blood glucose, and insulin in post-menopausal non-Asian women. Nine studies with 528 panelists for the parameter of body weight, 11 studies with 1,182 panelists for the parameter of blood glucose, and 11 studies with 1,142 panelists for the parameter insulin have been analyzed. These studies have demonstrated significant weight loss and a decrease in blood glucose and insulin in post-menopausal female panelists who had been given isoflavone as a supplement compared to the control group which was given a placebo. Furthermore, supplementation of isoflavone for a short time ( $<6$ months) could significantly decrease weight, while longterm supplementation ( $>6$ months) could significantly decrease blood glucose. A more significant weight loss was achieved through the consumption of a low dosage of supplement $(<100 \mathrm{mg})$ and for those who were overweight $(\mathrm{BMI}<30)$ compared to those who were obese $(\mathrm{BMI}>30)$.

\section{Tempe as a functional food in obesity treat- ment}

Considering the various potentials of the bioactive components in tempe as an antiobesity, tempe could be made into an appropriate diet menu. Yenrina et al. (2006) stated a survey of 2,080 households on Java Island revealed that they consumed processed soybean products such as tofu, tempe, oncom, soybean sprouts, tofu skin, and soy sauce in daily basis. Unfortunately, many of the processes involved frying, especially for tempe.

The frying process would increase fat intake (from the cooking oil absorbed by the product), indirectly increasing the caloric intake and could trigger obesity. Haron et al. (2009) stated that in $100 \mathrm{~g}$ raw tempe there is $205 \pm 56 \mathrm{mg}$ (dry weight) of isoflavone and the frying process would decrease the isoflavone by $45 \%$ to merely $113 \pm 41 \mathrm{mg}$ per $100 \mathrm{~g}$ (dry weight) of fried tempe. The correct tempe processing such as boiling or braising without frying or other processes that involve little fat could be considered as an alternative (Muaris 2016) in the optimation of tempe in obesity treatment diets.

Daily consumption of tempe in adequate amounts could support the daily plant-based protein and isoflavone intake. In 1995, the US FDA declared that a minimum of 25 grams of plantbased protein needs to be consumed daily as a part of a low fat and low cholesterol diet. Utari et al. (2011) suggested consumption of at least medium-sized slices of tempe (approximately 150 grams of tempe/day) cooked by steaming or boiling to improve the lipid profile. Consumption of that amount of tempe is equivalent to the consumption of $35 \mathrm{mg} /$ day of isoflavone and is in line with the recommended daily isoflavone consumption which is $30-100 \mathrm{mg} /$ day (Messina $\&$ Messina 2003). The effectiveness of tempe as a functional food in obesity cannot be achieved in a short time or with a certain dossage. Consuming tempe regularly with appropriate processing in the long term should be incorporated in the healthy living habit.

\section{CONCLUSION}

Based on the literature study, it is known that soybeans are beneficial in the treatment of obesity and its complications. Soybeans help reduce body weight and improve the body lipid condition. The bioactive components which are presumed to play a role are soybean protein, peptides, and isoflavone. The fermentation of soybeans into tempe can increase the amount and ability of these bioactive components. Optimation and popularization of tempe consumption as a functional food in the daily diet, supported with correct tempe processing (without frying), could be a solution in obesity treatment. 


\section{ACKNOWLEDGEMENTS}

The author would like to thank the Directorate of Research and Public Services, the Directorate of Research Strengthening and Development, the Ministry of Research, Technology, and Higher Education, aided this publication through the "Penelitian Berbasis Kompetensi 2018" scheme listed under Made Astawan.

\section{REFERENCES}

Ali AA, Velasquez MT, Hansen CT, Mohamed AI, Bhathen SJ. 2004. Effects of soybean isoflavones, probiotics, and their interactions on lipid metabolism and endocrine system in an animal model of obesity and diabetes. J Nutr Biochem 15(10):583-590.

Ali NM, Yeap S, Yusof HM, Beh B, Ho W, Koh S, Abdullah MP, Alitheen NB, Long K. 2016 Comparison of free amino acids, antioxidants, soluble phenolic acids, cytotoxity and immunomodulation of fermented mung bean and soybean. J Sci Food Agric 96(5):1648-1658.

Aoyama T, Fukui K, Takamatsu K, Hashimoto Y,Yamamoto T. 2000a. Soy protein isolate and its hydrolysate reduce body fat of dietary obese rats and genetically obese mice (yellow KK). Nutr 16(5):349-354.

Aoyama T, Fukui K, Nakamori T. 2000b. Effect of soy and milk whey protein isolates and their hydrolysates on weight reduction in genetically obese mice. Biosci Biotechnol Biochem 64(12):2594-2600.

Astawan M. 2008. Sehat dengan Tempe. Jakarta: PT Dian Rakyat.

Astawan M, Wresdiyati T, Widowati S, Bintari SH, Ichsani N. 2013. Karakteristik fisikokimia dan sifat fungsional tempe yang dihasilkan dari berbagai varietas kedelai. J Pangan 22(3):241-251.

Astawan M, Wresdiyati T, Sirait J. 2015. Pengaruh konsumsi tempe kedelai grobongan terhadap profil serum hematologi dan antioksidan tikus. J Teknol dan Industri Pangan 26(2):155-162.

Astawan M, Wresdiyati T, Maknun L. 2017. Tempe Sumber Zat Gizi dan Komponen Bioaktif untuk Kesehatan. Bogor: IPB Press.

Astuti M. 1997. Superoxide dismutase in tempe, an antioxidant enzyme and its implication on health and disease. Proceedings of the International Tempe Symposium 1997;
146-156. Indonesia: Yayasan Tempe Indonesia.

Barus T, Suwanto A, Wahyudi AT. 2008. Role of bacteria in tempe bitter taste formation; microbiological and molecular biological analysis based on 16S RNA gene. Microbiol Indones 2(1):17-21.

Bhathena SJ, Velasquez MT. 2002. Beneficial role of dietary phytoestrogens in obesity and diabetes. Am J Clin Nutr 76(6):11911201.

Cope MB, Erdman Jr JW, Allison DB. 2008. The potential role of soyfoods in weight and adiposity reduction: an evidence-based review. Obes Rev 9(3):219-235.

Efriwati, Nuraida L. 2013. Effect of two production methods on macro nutrient and isoflavones-aglycone composition in tempeh produced by household industries. Health Sci Indo 4(2):69-73.

Gibbs BF, Zougman A, Masse R, Mulligan C. 2004. Production and characterization of bioactive peptides from soy hydrolysate and soy-fermented food. Food Res Int 37(2):123-131.

Haron H, Ismail A, Azlan A, Shahar S, Peng LS. 2009. Daidzein and genestein contents in tempeh and selected soy products. Food Chem 115(4):1350-1356.

Hwang JT, Park IJ, Shin JI, Lee YK, Lee SK, Baik HW, Ha J, Park OJ. 2005. Genestein, EGCG and capcaisin inhibit adipocyte differentiation process via activating AMPactivated protein kinase. Biochem Biophys Res Commum 338(2):694-699.

Jang EH, Moon JS, Ko JH, Ahn CW, Lee HH, Shin JK, Park CS, Kang JH. 2008. Novel black soy peptides with antiobesity effects: activation of leptin-like signaling and AMP-activted protein kinase. Int $\mathrm{J}$ Obes 32(7):1161-1170.

Kagawa K, Matsutaka H, Fukuhama C. 1996. Globin digest, acidic protease hydrolysate, inhibits dietary hypertriglyceridemia and ValVal-Tyr-Pro, one of its constituents, possesses most superior effect. Life Sci 58(20):1745-1755.

Lee DS, Lee SH. 2001.Genestein, a soy isoflavone, is a potent a-glucosidase inhibitor. FEBS Letters 501(1):84-86.

Maiti D, Majumdar M. 2012. Impact of bioprocessing on phenolic content and antioxidant activity of spy seed to improve hypoglycemic functionality. Asian J Plant Sci Res 2(2):102-109. 
McCue P, Kwon YI, Shetty K. 2005. Anti-diabetic and anti-hypertensive potential of sprouted and solid-state bioprocessed soybean. APJCN 14(2):145-152.

Messina M, Messina V. 2003. Soy protein and isoflavone intakes for healthy adults: rationale. Nutr Today 38(3):100-109.

Muaris JH. 2016. Tempe Cuisine. Winarno FG, Winarno Wm Purnomo SH, Gunawan W (Eds). Bogor: Mbrio Press.

Nout MJR, Kiers JL. 2005. A review tempe fermentation, innovation, and functionality: update into the third millenium. J Appl Microbiol 98(4):789-805.

Sanchez-Magana LM, Cuevas-Rodriguez EO, Gutierrez-Dorado R, Ayala-Rodriguez AE, Valdez-Ortiz A, Milan-Carrillo J, ReyesMoreno C. 2014. Solid-state bioconversion of chickpea (Cicer arietinum L.) by Rhizopus oligosporus to improve total phenolic content, antioxidant, activity and hypoglygemic functionality. Int J Food Sci Nutr (Early Online): 1-7.

Shao S, Duncan AM, Yanga R, Marcone MF, Rajcan I, Tsao R. 2009. Tracking isoflavones: From soybean to soy flour, soy protein isolates to functional soy bread. $J$ Funct Foods 1(1):119-127.

Singh BP, Vij S, Hati S. 2014. Functional significance of bioactive peptides derived from soybean. Peptides 54:171-179.

Sugano M. 2006. Nutritional implication of soy. Di dalam: Sugano M, editor. Soy in Health and Diseases Prevention. New York: CRC Press.

Tope AK. 2014. Effect of fermentation on nutrient composition and anti-nutrient contents of ground Lima bean seeds fermented with Aspergillus fumigatus, Rhizopus stolonifer and Saccharomyces cerevisiae. Int $\mathrm{J}$ Adv Res 2(7):1208-1215.

Utari DM, Rimbawan, Riyadi H, Muhilal, Purwantyastuti. 2011. Potensi asam amino pada tempe untuk memperbaiki profil lipid dan diabetes mellitus. Kesmas 5(4):166170.
Velasquez M, Bhathena S. 2007. Role of dietary soy protein in obesity. Int J Med Sci 4(2):72.

Wang SM, Huang AHC. 1984. Inhibitors of lipase activities in soybean and other oil seeds. Plant Physiol 76(4):929-934.

Watanabe N, Endo Y, Fujimoto K, Aoki H. 2006. Tempeh-like fermented soybean (GABAtempeh) has an effective influence on lipid metabolism in rats. J Oleo Sci 55(8):391396.

[WHO] World Health Organization. 2011. 10 facts about diabetes. Terdapat di www. who.int/diabetes/en/accessed. Accessed on Oktober, $31^{\text {st }} 2014$.

Wijaya $\mathrm{CH}$, Gunawan MDPT, Kusumaningrum HD, Nurtama B, penemu; Institut Pertanian Bogor. 2007 Okt 4. Proses Pembuatan Tempe Melalui Pengasaman Kimiawi dengan Menggunakan Glukono delta lakton (GDL). Paten Indonesia ID P000035720.

Yang JY, Lee SJ, Park HW, Cha YS. 2006. Effect of genistein with carnitine administration on lipid parameters and obesity in C57B1/6J mice fed a high-fat diet. J Med Food 9(4):459-467.

Yenrina R, Yuliana, Muchtadi D. 2006. Pengolahan dan penerimaan produk kedelai pada rumah tangga di perkotaan dan pedesaan pulau Jawa Indonesia. J Gizi Pangan 1(1):36-43.

Yuliana ND, Jahangir M, Korthout H, Choi YH, Kim HK, Verpoorte R. 2011. Comprehensive review on herbal medicine for energy intake suppression. Obes Rev 12(7):499514.

Yun JW. 2010. Possible anti-obesity therapeutics from nature-A review. Phytochem. 71(1415):1625-1641.

Zhang YB, Chen WH, Guo JJ, Fu ZH, Cheng Y, Zhang M, Na XL. 2013. Soy isoflavone supplementation could reduce body weight and improve glucose metabolism in non-Asian postmenopausal women - A meta-analysis. Nutr 29(1):8-14. 